\title{
EXPLORATION OF BARRIERS PERCEIVED BY ONCOLOGY NURSES RELATED TO CANCER PAIN MANAGEMENT
}

\author{
Tahira Bibi', Ruqia Begum², Samina Kausar ${ }^{3}$, Samina Farooqi ${ }^{4}$ \\ ${ }^{1}$ Faculty of nursing in Govt teaching hospital, Shahdra, Lahore - Pakistan \\ ${ }^{2}$ Principal of Nursing children hospital, Lahore - Pakistan \\ ${ }^{3}$ Faculty of nursing, university of health sciences, Lahore - Pakistan \\ ${ }^{4}$ College of nursing Al-Aleem nursing college, Lahore - Pakistan
}

\begin{abstract}
Objectives: To explore barriers perceived by oncology nurses in cancer pain management.

Methods: A descriptive Cross sectional study was conducted in oncology department of four tertiary care hospitals of Punjab which include Mayo hospital Lahore, Jinnah hospital Lahore, Allied hospital Faisalabad and Nishtar hospital Multan. Sample size was calculated as 72 nurses by using WHO formula. Subjects were selected by purposive sampling technique from nurses working in oncology departments of four tertiary care hospitals. Research tool was adopted from previously published study with ethical permission. The data analysis was performed using SPSS version 20 and Microsoft excel. Descriptive statistics were used to analyze data.

Results: Four domains were covered in the results for exploration of barriers perceived by oncology nurses. Results showed that $97.3 \%$ nurses considered the lack of pain management training as barrier in pain management. From patient perspective, mood alteration of patient was responded by $87.7 \%$ nurses as barrier. $84.8 \%$ nurse perceived unavailability of physician at the time of pain as barrier and $95.9 \%$ perceived inappropriate nurse-patient ratio as barrier.
\end{abstract}

Conclusion: System related barriers were found more prevalent in cancer pain management from which inappropriate nurse -patient ratio was concluded most agreed barrier.

Key words: Pain, cancer pain, pain assessment, pain management, barriers

This article may be cited as: Bibi T, Begum R, Kausar S, Farooqi S. Exploration of barriers perceived by oncology nurses related to cancer pain management. J Med Sci 2021 July;29(3):79-82

\section{INTRODUCTION}

Cancer is a global health problem and second leading cause of death ${ }^{1}$. All over the world in 2020, there were an estimated 19.3 million new cases of cancer were reported, out of which roughly 10.0 million were pronounced dead ${ }^{2}$. In Pakistan, the incidence of cancer is estimated at 148,041 per year. During the period of last five years over 100,000 deaths due to cancer was reported and prevalence of diagnosed patients were $350,000^{3}$. Although patient with cancer presents with multiple symptoms but pain is most predominant and distressing symptom of cancer that affects the quality of life of patient as

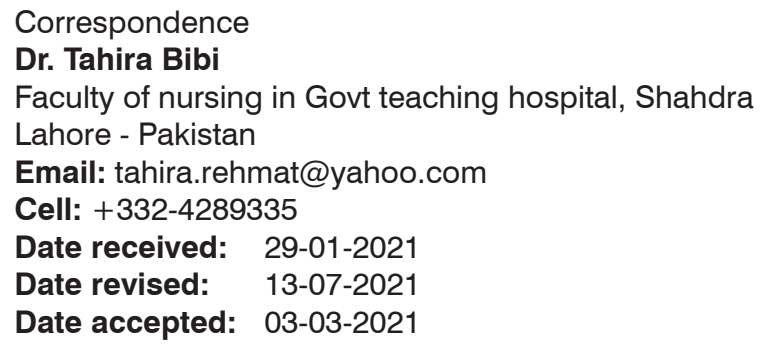

well as family in all aspects. Not only the disease of cancer is painful but the treatment like chemotherapy is also pain full that creates hindrance in the prognosis of disease.

This lead to many complications such as anxiety and sleep disturbance and increase patient stay in hospital $^{4}$. Despite of persistent work done on pain management and introduction of advance therapies only slight improvements have been achieved and still $45.6 \%$ of the patients reported pain in early stage of cancer while $73.9 \%$ of the patients reported severe pain in advanced stage of cancer in many settings ${ }^{5}$.

Oncology nurses are considered to have an obvious role in managing the pain of patients suffering from cancer. However, It is observed that nurses face multiple factors as barriers that cause them to inefficiently participate in assessment and management of pain ${ }^{5-7}$. These barriers are lack of pain management specialists in the health care team, improper nurse to patient ratio, religious and cultural misconception about the cancer pain ${ }^{8}$. Al- 
though many studies were conducted on pain management still there is limited data on the nurses' perceived barriers to optimal pain management in cancer patients in Pakistan. Hence this study is conducted to explore the barriers perceived by oncology nurses for the management of cancer pain.

\section{MATERIAL AND METHODS}

A descriptive Crossectional study was conducted in oncology department of four tertiary care hospitals including Mayo hospital Lahore, Jinnah hospital Lahore, Nishtar hospital Multan and Allied hospital Faisalabad from August 2019-December 2019. The sample size was calculated by $\mathrm{WHO}$ formula.

Equal numbers of subjects were selected from each hospital according to inclusion criteria. Female Nurses working in oncology department who had more than one-year general nursing experience and more than sixmonth experience in oncology department were include in this study.

Male nurses and LPN were excluded ${ }^{18}$. Permission was taken from ethical review committee and administration of hospital to conduct study. After taking permission data were collected from participants by questionnaire. The questionnaire was adopted from previously published study with ethical permission ${ }^{9}$.

The reliability and validity of questionnaire was checked by one previous study and reliability value was found $0.8^{10}$. Four themes as nurses related, patient related, physician related and system related barriers were developed to explore the barriers in pain management. Likert scale was used to measure responses.

After the response of participants different numbers were assigned to the responses as 1 for agree, 2 for Neutral, 3 for Disagree in the questionnaire. After collection data was analyzed by SPSS version 20. Descriptive statistics test as-percentages and frequencies were used to analyse the data.

\section{RESULTS}

In this study Likert scale was used to assess the responses of respondents. Three degrees were used as agree, neutral and disagree. The responses more than $50 \%$ were considered as barriers. Table No 1 shows the analysis of the participants' responses on nurses'- relat- ed barriers. Table No 2 reveals the distribution of subjects according to patient related barriers. Table No 3 identifies the nurses' perception about physician related barriers. Table No 4 reveals the analysis of nurses' responses for institution related barriers.

Table 1: Nurse's related barriers

\begin{tabular}{|c|c|c|c|}
\hline Age Group & Agree $\mathbf{n} \%$ & Neutral n\% & $\begin{array}{c}\text { Disagree } \\
\mathbf{n} \%\end{array}$ \\
\hline $\begin{array}{c}\text { Inadequate } \\
\text { training to pain } \\
\text { management }\end{array}$ & $70(97.3)$ & $2(2.8)$ & $0(0)$ \\
\hline $\begin{array}{c}\text { Inadequate } \\
\text { knowledge to pain } \\
\text { assessment }\end{array}$ & $51(70.8)$ & $8(11.1)$ & $13(18.1)$ \\
\hline $\begin{array}{c}\text { Inadequate knowl- } \\
\text { edge to deliver } \\
\text { nonpharmacologi- } \\
\text { cal Intervention }\end{array}$ & $51(70.8)$ & $14(19.4)$ & $7(9.7)$ \\
\hline $\begin{array}{c}\text { Reluctant to } \\
\text { administer opiates } \\
\text { due to strict nar- } \\
\text { cotic policy }\end{array}$ & $49(68)$ & $5(6.9)$ & $17(26)$ \\
\hline $\begin{array}{c}\text { Lack of time for } \\
\text { health teaching to } \\
\text { patients and their } \\
\text { families }\end{array}$ & $51(70.8)$ & $10(13.9)$ & $11(15.3)$ \\
\hline $\begin{array}{c}\text { Lack of proper } \\
\text { pain assessment } \\
\text { tools application }\end{array}$ & $45(62.5)$ & $6(8.3)$ & $21(29.2)$ \\
\hline $\begin{array}{c}\text { Nurses indiffer- } \\
\text { ence to patient's } \\
\text { pain complains }\end{array}$ & $38(52.8)$ & $9(12.5)$ & $25(34.7)$ \\
\hline
\end{tabular}

Table 2: Distribution of subject according to patient related barriers

\begin{tabular}{|c|c|c|c|}
\hline Age Group & Agree $\mathbf{n} \%$ & $\begin{array}{c}\text { Neutral } \\
\mathbf{n} \%\end{array}$ & $\begin{array}{c}\text { Disagree } \\
\mathbf{n} \%\end{array}$ \\
\hline $\begin{array}{c}\text { Patients have difficulty } \\
\text { to rate their pain on } \\
\text { pain scale }\end{array}$ & $59(81.9)$ & $12(16.7)$ & $1(1.4)$ \\
\hline $\begin{array}{c}\text { Patients are reluctant to } \\
\text { take medication due to } \\
\text { fear of addiction }\end{array}$ & $37(51.4)$ & $5(6.9)$ & $30(41.6)$ \\
\hline $\begin{array}{c}\text { Mood alterations } \\
\text { produce difficulty for } \\
\text { nurses to manage pain }\end{array}$ & $63(87.5)$ & $6(8.3)$ & $3(4.2)$ \\
\hline $\begin{array}{c}\text { Patients prefer to report } \\
\text { pain to doctor, but not } \\
\text { to nurses }\end{array}$ & $23(33)$ & $8(11.1)$ & $41(57)$ \\
\hline $\begin{array}{c}\text { Misconception that } \\
\text { pain medication cannot } \\
\text { control cancer pain }\end{array}$ & $25(34.8)$ & $9(12.5)$ & $38(52.8)$ \\
\hline $\begin{array}{c}\text { Patients are afraid of } \\
\text { being labeled as com- } \\
\text { plainer }\end{array}$ & $30(41.7)$ & $6(8.3)$ & $36(50)$ \\
\hline $\begin{array}{c}\text { Communication } \\
\text { barriers }\end{array}$ & $49(68)$ & $11(15.3)$ & $12(16.7)$ \\
\hline
\end{tabular}


Table 3: Distribution of subjects according to physician related barriers

\begin{tabular}{|c|c|c|c|}
\hline Age Group & $\begin{array}{c}\text { Agree } \\
\mathbf{n \%}\end{array}$ & $\begin{array}{c}\text { Neutral } \\
\mathbf{n} \%\end{array}$ & $\begin{array}{c}\text { Disagree } \\
\mathbf{n} \%\end{array}$ \\
\hline $\begin{array}{c}\text { Shortage of time for } \\
\text { proper pain assessment }\end{array}$ & $44(61.1)$ & $11(15.3)$ & $17(23.6)$ \\
\hline $\begin{array}{c}\text { Reluctant to prescribe } \\
\text { opiates because of the } \\
\text { side effects }\end{array}$ & $37(51.4)$ & $9(12.5)$ & $26(36.1)$ \\
\hline $\begin{array}{c}\text { Inadequate knowledge to } \\
\text { assess pain }\end{array}$ & $32(44.5)$ & $17(23.6)$ & $23(32.6)$ \\
\hline $\begin{array}{c}\text { Fear of legal and admin- } \\
\text { istrative constraint for } \\
\text { opiate prescription }\end{array}$ & $47(65.2)$ & $8(11.1)$ & $17(23.7)$ \\
\hline $\begin{array}{c}\text { Lack of pain manage- } \\
\text { ment training to the } \\
\text { physicians }\end{array}$ & $12(16.7)$ & $9(12.5)$ & $51(70.8)$ \\
\hline $\begin{array}{c}\text { Unavailability of physi- } \\
\text { cian at the time of pain }\end{array}$ & $61(84.8)$ & $6(8.3)$ & $5(6.9)$ \\
\hline Physician's indifference & $46(63.9)$ & $16(22.2)$ & $10(13.9)$ \\
\hline
\end{tabular}

Table 4: Distribution of subjects according to institution related barriers

\begin{tabular}{|c|c|c|c|}
\hline Age Group & $\begin{array}{c}\text { Agree } \\
\mathbf{n} \%\end{array}$ & $\begin{array}{c}\text { Neutral } \\
\mathbf{n} \%\end{array}$ & $\begin{array}{c}\text { Disagree } \\
\mathbf{n} \%\end{array}$ \\
\hline $\begin{array}{c}\text { Lack of institutional policy } \\
\text { and guide line for pain } \\
\text { management }\end{array}$ & $55(76.4)$ & $6(8.3)$ & $11(15.3)$ \\
\hline $\begin{array}{c}\text { Ratio of nurses are not } \\
\text { according to patients }\end{array}$ & $69(95.9)$ & $3(4.2)$ & $00(0)$ \\
\hline $\begin{array}{c}\text { Lack of non-pharma- } \\
\text { cologic therapy of pain } \\
\text { Management (cold, hot, } \\
\text { acupuncture etc.) }\end{array}$ & $62(82.1)$ & $09(12.5)$ & $01(1.4)$ \\
\hline $\begin{array}{c}\text { Strict Narcotic prescrip- } \\
\text { tion regulation }\end{array}$ & $47(65.2)$ & $9(12.5)$ & $16(22.3)$ \\
\hline $\begin{array}{c}\text { Lack of specialized pain } \\
\text { management team }\end{array}$ & $47(65.2)$ & $3(4.2)$ & $22(30.6)$ \\
\hline $\begin{array}{c}\text { Lack of psychosocial I } \\
\text { support system to patient } \\
\text { and family }\end{array}$ & $64(88.9)$ & $8(11.1)$ & $00(0)$ \\
\hline $\begin{array}{c}\text { Lack of coordination } \\
\text { across health care pro- } \\
\text { viders }\end{array}$ & $46(63.9)$ & $11(15.3)$ & $15(20.8)$ \\
\hline
\end{tabular}

\section{DISCUSSION}

The current study was carried out to explore the barriers that nurses perceived in the management of cancer pain and have agreement with previous studies that nurse's related barriers exist and produce difficulty in pain management. Among nurse's related barriers, inadequate training to nurses for pain management, inadequate time for pain assessment, inadequate time for health teaching and non-pharmacological interventions were found most agreed barrier that put stress on the call for training of nurses on pain management ${ }^{11-15}$.
With respect to patient related barriers, current study showed same results as previous studies reported that pain is often minimally or under report by patients for reasons based on their own understanding about pain scale. The results of this study contradict with the results of previous studies that pain management was a key responsibility of doctors and patients report pain to the doctors but not the nurses, also conceal their pain and refuse to take pain medication due to fear of addiction because in this study it was found that nurses were not considered these barrier ${ }^{16-18}$.

The findings of this study also match with some previous studies that physicians have lack of time and knowledge to assess pain and also are reluctant to prescribe pain medication due to fear of addiction and strict institutional policies. Moreover it was found a great barrier that physician are not present at the time of pain $5,21,19$.

Majority of studies concluded that Institution related barriers were most rated barrier in pain management. The results of this study match with previous studies, that lack of institutional policies, inappropriate nurse-patient ratio, unavailability of nonpharmacological measures produced hurdle in pain management and made nurses unable to control pain ${ }^{13,20}$.

This study is restricted to cancer pain management. Further studies can be conducted on other perspectives of pain. A large sample size will be needed to validate the study. This study was confined to four tertiary care hospitals. It can be replicate with increased sample size and in other hospitals of Pakistan.

\section{CONCLUSION}

This study explored the barriers perceived by oncology nurses related to cancer pain management. The results of this study explored that from four groups of barriers institutional and nurses related barriers were found more prevalent. Among all these barriers inappropriate nurse-patient ratio was found most agreed barrier.

\section{ACKNOWLEDGEMENT}

I am thankful to my supervisor and my colleague Miss Samina Farooqi, helping me to write this article.

\section{REFERENCES}

1. Arshad S, ur Rehman M, Abid F, Yasir S, Qayyum M, Ashiq $\mathrm{K}$, et al. Current situation of breast cancer in Pakistan with the available interventions. Int $\mathrm{J}$ Biosci. 2019;11(6):232-40.

2. Ferlay J, Colombet M, Soerjomataram I, Parkin DM, Piñeros M, Znaor A, et al. Cancer statistics for the year 2020: An overview. nt J Cancer. 2021 Apr 5. doi: 10.1002/ ijc.33588. Epub ahead of print. PMID: 33818764.

3. Yusuf A. Cancer care in Pakistan. Jpn J Clin Oncol. 2013 Aug;43(8):771-5. doi: 10.1093/jjco/hyt078. Epub 2013 
Jun 7. PMID: 23749983.

4. Huijer HA-S. Pain Management and Palliative Care: A Program of Research. Published online July 13, 2016.

5. Nyirigira G, Wilson RA, VanDenKerkhof EG, Goldstein $\mathrm{DH}$, Twagirumugabe T, Mahaffey $\mathrm{R}$, et al. Barriers and facilitators to postoperative pain management in Rwanda from the perspective of health care providers: A contextualization of the theory of planned behavior. Can J Pain 2018;2(1):87-102.

6. Shoqirat N. 'We are nurses, they are doctors': barriers to nurses' roles in pain management following surgery in Jordan. Int J Nurs Pract. 2015 Apr;21(2):200-6. doi: 10.1111/ijn.12240. Epub 2014 Oct 13. PMID: 25307454.

7. Lebaron V, Beck SL, Maurer M, Black F, Palat G. An ethnographic study of barriers to cancer pain management and opioid availability in India. Oncologist. 2014;19(5):515522. doi:10.1634/theoncologist.2013-0435

8. Lakha SF, Pennefather P, Agboatwala M, Siddique SZ, Badr HE, Mailis-Gagnon A. Chronic Non-Cancer Pain Management Capacity in Karachi. Pain Ther. 2017 Dec;6(2):179-191. doi: 10.1007/s40122-0170072-7. Epub 2017 May 29. PMID: 28555331; PMCID: PMC5693803.

9. Elcigil A, Maltepe H, Eşrefgil G, Mutafoglu K. Nurses' perceived barriers to assessment and management of pain in a university hospital. J Pediatr Hematol Oncol. 2011 Apr;33 Suppl 1:S33-8. doi: 10.1097/MPH.0b013e3182121 bef. PMID: 21448032.

10. Czarnecki ML, Guastello A, Turner HN, Wrona SK, Hainsworth KR. Barriers to Pediatric Pain Management: A Brief Report of Results from a Multisite Study. Pain Manag Nurs. 2019 Aug;20(4):305-308. doi: 10.1016/j. pmn.2019.01.008. Epub 2019 May 15. PMID: 31103499.

11. Bouya S, Balouchi A, Maleknejad A, Koochakzai M, AlKhasawneh E, Abdollahimohammad A. Cancer Pain Management Among Oncology Nurses: Knowledge, Attitude, Related Factors, and Clinical Recommendations: a Systematic Review. J Cancer Educ. 2019 Oct;34(5):839846. doi: 10.1007/s13187-018-1433-6. PMID: 30315497.

12. Samarkandi OA. Knowledge and attitudes of nurses toward pain management. Saudi J Anaesth. 2018;12(2):220-226. doi:10.4103/sja.SJA_587_17

13. Al-Mahrezi A. Towards Effective Pain Management: Breaking the Barriers. Oman Med J. 2017;32(5):357-358. doi:10.5001/omj.2017.69

14. Uysal N. Clearing Barriers in Cancer Pain Management: Roles of Nurses. Int J Caring Sci. 2018;11(2).

15. Toba HA, Samara AM, Zyoud SH. Nurses' knowledge, perceived barriers, and practices regarding cancer pain management: a cross-sectional study from Palestine. BMC Med Educ. 2019 May 23;19(1):167. doi: 10.1186/s12909-019-1613-z. PMID: 31122222; PMCID: PMC6533684.

16. Dyal BW, Ezenwa MO, Yao Y, Molokie RE, Wang ZJ, Ballas SK, Suarez ML, Wilkie DJ. Randomized clinical trial of computerized PAINRelievelt ${ }^{\circledR}$ for patients with sickle cell disease: PAINReportlt ${ }^{\circledR}$ and PAINUCope ${ }^{\circledR}$. Patient Educ Couns. 2020 Jan;103(1):136-144. doi: 10.1016/j. pec.2019.08.021. Epub 2019 Aug 17. PMID: 31451364; PMCID: PMC6895421.

17. Konstantis A, Exiara T. Family caregiver beliefs and barriers to effective pain management of cancer patients in home care settings. J BUON. 2018 Dec;23(7):144-152. PMID: 30722124.

18. Lou F, Shang $S$. Attitudes towards pain management in hospitalized cancer patients and their influencing factors. Chin J Cancer Res. 2017;29(1):75-85. doi:10.21147/j.issn.1000-9604.2017.01.09

19. D'emeh WM, Yacoub MI, Darawad MW, Al-Badawi TH, Shahwan B. Pain-related knowledge and barriers among Jordanian nurses: a national study. Health. 2016;8(06):548.

20. Brunkert T, Simon M, Ruppen W, Zúñiga F. A Contextual Analysis to Explore Barriers and Facilitators of Pain Management in Swiss Nursing Homes. J Nurs Scholarsh. 2020 Jan;52(1):14-22. doi: 10.1111/jnu.12508. PMID: 31898860 .

CONFLICT OF INTEREST: Authors declare no conflict of interest

GRANT SUPPORT AND FINANCIAL DISCLOSURE: NIL

\section{AUTHOR'S CONTRIBUTION}

Following authors have made substantial contributions to the manuscript as under

Bibi T: $\quad$ Data collection writing

Begum R: Data collection and Review

Kausar S: Statistical analysis and Review

Farooqi S: Discussion writing and Review

Authors agree to be accountable for all aspects of the work in ensuring that questions related to the accuracy or integrity of any part of the work are appropriately investigated and resolved. 